\title{
EXPLORAÇÃO DO TRABALHO INFANTIL: EM BUSCA DA CULTURA LÚDICA NO ÂMBITO DA REGIÃO DA CANA-DE-AÇÚCAR DO NORDESTE DO BRASIL ${ }^{1}$
}

\author{
Maurício Roberto da Silva ${ }^{2}$
}

\begin{abstract}
(...) Ao ver como se pregam e se jogam homens e mulheres em virtude de um mercado de trabalho errático, cada vez mais imaginário, comparável àquela "pele de onagro" que se encolhe, um mercado do qual eles dependem, do qual suas vidas dependem, mas que não depende deles; ao ver como já não são contratados (grifos meus) com tanta freqüência, e como vegetam em particular os jovens (grifos meus), numa vacuidade sem limites, considerada degradante, e como são detestados por isso; ao ver como, a partir daí, a vida os maltrata e como a ajudamos a maltratá-los; ao ver que, para além da exploração dos homens, havia algo ainda pior: a ausência de qualquer exploração como deixar de dizer que, não sendo sequer exploráveis (grifos meus), nem sequer necessárias à exploração, ela própria inútil, as multidões podem tremer, e cada um dentro da multidão? $\{. .$.$\} Então como um eco aquela pergunta: "Será útil viver quando$ não se é lucrativo ao lucro?", ela própria eco daquela outra: "É preciso merecer viver para ter esse direito? Surge o temor insidioso, o medo difuso, mas justificado, de ver um grande número de seres humanos considerados supérfluos (grifos meus). Não subalternos nem reprovados: supérfluos.. e por essa razão, nocivos(grifos meus). E por essa razão...[...] incluídos até a medula...
\end{abstract}

Viviane Forrester

\section{E tudo continua como dantes?}

(...) O passado não reconhece o seu lugar está sempre presente.

(Mário Quintana)

Esta investigação traz para o debate a problemática interdisciplinar e multidimensional da "exploração do trabalho infantil", cujo objetivo primeiro é: “investigar no âmbito da exploração do trabalho infantil, o mundo da cultura lúdica das crianças trabalhadoras, empobrecidas e exploradas da Zona da Mata canavieira pernambucana, localizada no Nordeste brasileiro". Como a tese foi defendida em 2000 e o livro publicado em 2003, o segundo objetivo deste texto é, simultaneamente ao primeiro, "trazer de volta os dados e resultados obtidos durante o processo de produção da tese e publicação do livro, visando, com isso, na medida do possível, revisitar, os dados, no sentido de verificar se, em razão das ações e promessas da OIT/IPEC e do governo brasileiro, foi possível "erradicar o trabalho infantil" ou se todo isso não passa de um grande alarde em torno desta problemática". Este último objetivo se justifica, articulando-se ao primeiro, considerando que, a despeito dos organismos internacionais

\footnotetext{
${ }^{1}$ As idéias deste texto originam-se da tese de Doutoramento, defendida em 2000 na Faculdade de Educação/Departamento de Ciências Sociais Aplicadas à Educação/UNICAMP, cujo título é O assalto à infância no mundo amargo da cana-de-açúcar. onde está o lazer? o gato comeu !!!??? e, posteriormente, transformada em livro intitulado Trama Doce-Amarga: Exploração do trabalho Infantil e Cultura Lúdica.São Paulo; Ijuí: HUCITEC, UNIJUÍ, 2003.

${ }^{2}$ NEPEF - Núcleo de Estudos Pedagógicos.Centro de Desportos/Departamento de Educação Física Universidade de Santa Catarina. e-mail: mauran@uol.com.br
} 
(OIT) e o governo brasileiro com suas políticas "sociais" de "inclusão", enunciarem em seus discursos a suposta diminuição das taxas do trabalho infantil ou a sua eliminação.Se isto fosse verdade e se não fosse o grande número de crianças na rua ou entregues á "exploração invisível” do trabalho infantil; se não fosse o grande número de pais e mães desempregados e seus filhos e filhas tendo que substituí-los como provedores da família - estaríamos todos a celebrar ao fato de vermos as crianças da classe trabalhadora em escolas de qualidade e dedicadas a tecer os fios imaginários, simbólicos e reais da cultura lúdica - mas, infelizmente, a história se repete sempre, conforme os versos do poeta Mário Quintana na abertura deste texto.

Neste sentido, as "questões de pesquisa" que norteiam a investigação são as seguintes: "a lógica da exploração capitalista, com toda a sua carga destrutiva do trabalho alienado, conseguiu suprimir total ou parcialmente o tempo "livre" das crianças para o usufruto da cultura lúdica? Além disso, "se os dados encontrados na tese de doutoramento (2000) e no projeto do livro "Trama Doce-Amarga: (Exploração do) Trabalho Infantil e Cultura lúdica", publicado por mim em 2003 - ainda prevalecem ou sofreram modificações ao longo dos últimos quatro anos - em razão das ações da OIT e das políticas sociais do governo brasileiro? Finalmente - é possível erradicar o trabalho infantil pela raiz na perspectiva da lógica do capitalismo neoliberal, não só na zona canavieira do estado de Pernambuco, mas em todo o Brasil, considerando as novas configurações do mundo do trabalho (desemprego, precarização, flexibilização)? Assim, o recorte desta investigação se constitui, não apenas, na constatação ou análise dos dados sobre danos e "múltiplos constrangimentos" para as subjetividades infantis, causados pela exploração do trabalho infantil na cana-de-açúcar (e em outros mundos do trabalho urbano-rural), mas as possibilidades concretas de táticas de resistência, rebeldia e transgressão que as crianças, contraditoriamente, constroem no âmbito de social, também eivada de contradições, desafios, lutas, conformismos, resistências, consensos e conflitos.

No período de 1996 a 2003, os resultados já indicavam, que as crianças constroem suas "táticas de resistência", a partir das ações das culturas lúdicas, articuladas com as lutas políticas dos adultos trabalhadores ("campanhas salariais"), cujo pano de fundo da exploração do trabalho e destruição de suas infâncias. Ficou constatado que, apesar do caráter emancipatório (resistências, transgressões etc), demonstrado pelas crianças e jovens nos de lazer (jogos, brinquedos e brincadeiras) e pelas lutas e participações políticas dos pais e dos adultos em geral junto aos sindicatos, 
pode-se dizer que os "direitos" das crianças continuam sendo desrespeitados, no que se refere á relação imbricada entre "trabalho", "educação" e "tempo livre". Essa constatação é de suma importância, considerando que a legislação brasileira que defende os direitos das crianças, nomeadamente, o "Estatuto da Criança e do Adolescente" em seus capítulos "IV", "V", apesar de exercer uma certa influência, no que pese a defesa de alguns pontos da agenda da infância (educação, trabalho e lazer), não consegue, muitas vezes, ir além do que uma mera cidadania cartorial. Os dados e as fontes (documentais, teóricas e estatísticas) referentes a este texto são relativos ao período em que a investigação foi realizada, nomeadamente, de 1996 a 2000 e, posteriormente, atualizadas, no momento em que a tese de doutoramento foi publicada em 2003, convertendo-se, portanto, no livro "Trama Doce-Amarga: (Exploração do) Trabalho Infantil e Cultura lúdica", além de dados mais recentes (DIEESE, OIT, Centro Josué de Castro e outros).

Após sete anos de estudos, os resultados indicam que há um mito em torno da "erradicação do trabalho infantil", por parte das políticas públicas, respectivamente, Bolsa Escola (Criança Cidadã) e na atualidade a "Bolsa família" (PETI - Programa de Erradicação do Trabalho Infantil), implementadas nos dois últimos governos do Brasil (Fernando Henrique Cardoso e Luís Inácio Lula da Silva). As estatísticas, calcadas, em métodos unicamente quantitativos, apontam para uma suposta diminuição do "trabalho infantil" e nem sempre da "exploração do trabalho infantil", a partir dos "efeitos" dos chamados programas de "geração de renda", os quais tem caráter apenas de política provisória, assistencialista e paternalista, cujo jargão (marketing político), propaga a “inclusão social" e a aquisição de "cidadania". Sendo assim, esta pesquisa procura problematizar os conceitos auto-explicativos e vazios no ponto de vista teórico no âmbito dos documentos da política pública PETI. Convém lembrar, também, em termos de resultados, que a "exploração do trabalho infantil" e não o "trabalho infantil" em geral se dá no âmbito da destruição da força humana de trabalho dos adultos no Brasil em geral e, sobretudo, nos canaviais pernambucanos e, da conseqüente, substituição dos adultos pelas crianças e jovens e da "inclusão" destes, em idade prematura, nos postos de trabalho dos trabalhadores adultos.

A própria OIT/IPEC, afirma, todavia, que suas ações, vêm, de forma estratégica e oportuna, conseguindo [...] potencializar os vários movimentos no País em defesa dos direitos da criança e do adolescente por meio de duas convenções complementares fundamentais que tratam do trabalho infantil: Convenção $n^{\circ} 138$ (Idade Mínima) e 
Convenção $n^{\circ} 182$ (Piores Formas). Assim, com mais de 100 programas de ação financiados pela OIT, mostrou que é possível não somente implementar políticas integradas de "retirada" (grifos meus) e proteção da criança e do adolescente do trabalho precoce, como também desenhar ações preventivas junto à família, escola, comunidade e à própria criança. De acordo com a OIT há um inegável sucesso do OIT/IPEC, no que se refere à erradicação do trabalho infantil, uma vez que a agenda das políticas nacionais traduz os maiores índices de redução do número absoluto de crianças exploradas no trabalho formal que se tem notícia. No entanto, a OIT/IPEC continua a cooperar com a sociedade brasileira para progressivamente retirar as 5 milhões de crianças e adolescentes restantes (das 8,4 milhões existentes, entre 5 e 17 anos no início da década de 90, de acordo com dados da Pesquisa Nacional por Amostra de Domicílios - PNAD 2001, do Instituto Brasileiro de Geografia e Estatística - IBGE). Essas se encontram no trabalho informal, perigoso, ilícito e oculto, cujos desafios não são menores do que eram quando o IPEC se estabeleceu no Brasil há mais de 10 anos $^{3}$.

Se mantivermos o olhar apenas para os dados quantitativos celebrados pelo governo brasileiro, pela OIT e pelas ONG's, vamos perceber que, na aparência, a "erradicação do trabalho infantil", do modo como vêm sendo concebida, de fato, apresenta resultados "positivos", como exemplo: maior visibilidade na Mídia e uma certa consciência social acerca desta problemática. Nesta direção, Di Giovani (2004 p. 39), ao fazer um balanço em seu livro chancelado pela OIT e intitulado "Aspectos qualitativos do trabalho infantil no Brasil" - afirma que é um fato a evidente diminuição do trabalho infantil no Brasil - concomitantemente com a expansão de um conjunto de políticas sociais, entre elas o programa de transferência de rendimentos e outras que propiciaram a expansão da escolaridade e da escolarização. Todavia, penso que faltou ao autor, agregar aos "aspectos qualitativos" - outros dados quantitativos do PNAD IBGE (2006), os quais afirmam que "o trabalho infantil cresceu de 10,3\% de 2004 para 2005. De acordo com esta instituição, o aumento das taxas foi influenciado pela atividade agrícola, que, em 2005, detinha 76,7\% das crianças de 5 a 9 anos de idade ocupadas ${ }^{4}$. Para além, destas avaliações quantitativas e, supostamente, "qualitativas", penso que ser imprescindível não olvidar o fenômeno da "migração" das crianças e jovens que outrora trabalhavam na cana, provavelmente, já atendidas pelo PETI e, hoje desempenham um tipo de trabalho clandestino e invisível, qual seja: casas de farinha,

\footnotetext{
${ }^{3}$ http://www.oitbrasil.org.br/

${ }^{4}$ Cf. o Site http://www.pernambuco.com/
} 
lixões, malabarismos nos semáforos das grandes e médias cidades, o trabalho doméstico, sobretudo, feminino e em outras atividades laborais ${ }^{5}$.

No entanto, quando fazemos uma leitura qualitativa desses dados no Brasil no mundo do trabalho sulcro-canavieiro (desemprego, subemprego, êxodo rural, falência das usinas etc) e outros ${ }^{6}$, vamos perceber, se levarmos em conta que a exploração do trabalho humano está presente, de forma visível e invisível, "tolerável"e "intolerável" em todo o planeta, sobretudo, nos chamados países periféricos, que a epígrafe de Viviane Forrester supracitada, de algum modo - contradiz o suposto fim da exploração da força humana de trabalho das crianças.

$\mathrm{Na}$ pesquisa "O trabalho tolerado até os 14 anos", encomendada pela CNTE (Confederação Nacional dos Trabalhadores da Educação ao DIEESE) é possível percebera crítica subrepitícia aos programas erradicação do trabalho infantil da OIT. A pesquisa se refere ao destaque dado diversas mídias aos trabalhos reconhecidos, imediatamente, como "intoleráveis"como o corte de cana-de-açúcar, carvoarias e produção de sisal - mas também as crianças que vivem praticamente nas ruas dos grandes centros urbanos, fazendo todo o tipo de trabalho precário (bicos) para sobreviver. Esta constatação nos leva à inferir que a exploração do trabalho infantil no Brasil está restrito a esses casos limites (intoleráveis), fato este que poderá trazer distorções ao projeto de "erradicação" e, mais ainda por em xeque os métodos quantitativos de avaliação da problemática em pauta.

Pelo visto, a OIT só fala de "trabalho infantil" que requer medidas políticas em relação a aquelas atividades laborais que estão proibidas nas Convenções da OIT, nomeadamente, 138 e 182. Assim sendo, com esta forma de conceber o problema, o trabalho realizado por crianças (maiores de 12 anos) que trabalham algumas horas por semana em uma atividade "permitida" e também as crianças maiores de 15 anos, cujo trabalho é considerado "perigoso", não é "trabalho infantil". Neste sentido, o trabalho infantil só é uma categoria jurídica e, por isso, definido a partir de conceitos jurídicos, daqueles que, tacitamente, se presume que são "adequados" e "do interesse" das crianças. Isso vale também para as crianças que realizam os chamados trabalhos

\footnotetext{
${ }^{5}$ Cf. o site http://www.pernambuco.com/, o jornal "Diário de Pernambuco" (2003, 2004 e 2005) e o Instituto Josué de Castro, UNICEF.

${ }^{6}$ DIEESE (Boletim 193 - http://www.dieese.org.br/.
} 
perigosos.Esta categoria nasce também das pautas jurídicas das convenções da OIT, em especial, da 182 (LIEBEL, 2003) ${ }^{7}$.

A vida cotidiana das crianças canavieiras, assim como de outros mundos da exploração do trabalho infantil, encontra-se imersas na racionalidade destrutiva do capital (da força humana de trabalho, da coletividade; direitos dos trabalhadores, sindicatos, associações cooperativas, família; etc; do meio ambiente, da infância, da juventude, da velhice, enfim das relações sociais (Bourdieu, 1999; Kurz, 1996; Antunes, $1995)^{8}$, torna-se inevitável não levar em consideração de que a situação por que passa e, ao longo séculos, sempre passou, a infância e juventude brasileiras, oriundas das classes trabalhadoras empobrecidas, tanto rural quanto urbana, também faz parte de todo esse processo global gradativo e destrutivo supramencionado. Neste sentido, os depoimentos das próprias crianças coletados no período de 1996 e 2003, contém uma crítica social, apontando denúncias contra as marcas da exploração precoce, anunciando, sub-repticiamente, um outro projeto de sociedade. Seus sonhos-desejados, seus tempos "não livre"e exíguos para os jogos e brincadeiras, suas críticas e seus apelos expõem as feridas e as marcas do envelhecimento precoce deixadas em seus corpos pelas políticas sociais iníquas impostas pelo sistema capitalista: (...) Agente fica velho logo mas isso não pode ser , porque a criança é uma pessoa que nasceu hoje. (...) O rosto e o corpo fica com os arranhões da cana e do carvão da queimada, a pele fica com manchas.(...) Se tivesse estudando e brincando crescia mais forte, mais bonito e com mais saúde e quando cresce pode ser um homem muito forte (Elielson José da Silva, 12 anos-Catende).

Como se pode constatar, a situação das crianças e jovens do meio rural brasileiro, em especial, as da Zona da Mata canavieira pernambucana ou Mesoregião e, que podem ser chamadas "não-crianças" e não "crianças carentes de infância" afirmam Sarmento e Marchi (2007) ${ }^{9}$, contrapondo-se a Martins (1995). Essas crianças, em sua grande maioria, filhas da classe trabalhadora empobrecida e vilipendiada pela racionalidade econômica destrutiva do capital, continuam a saga transgeracional da

\footnotetext{
${ }^{7}$ Para mayor información sobre estas experiencias y propuestas, véase en la red www.ifejants.org (esp.), www.workingchild.org (ingl.), www.enda.sn/eja (ingl. y francés), www.italianats.org y www.pronats.de, así como el libro: M. Liebel, Infancia y Trabajo, IFEJANT, Lima, 2003.

${ }^{8}$ Cuja ação predadora é imposta aos chamados países periféricos, através dos planos de ajuste ou cardápios do FMI e do Banco Mundial (Chossudovsky, 1999, Galeano, 1999).

${ }^{9}$ Refiro-me ao paradigma "crítico" da Sociologia da Infância, de acordo com Sarmento e Marchi (2007), no qual a concepção de infância é, simultaneamente, uma construção social, um grupo oprimido e uma "condição social" isto é, um grupo que vive condições especiais de "exclusão", isto é, a "não-criança".
} 
exploração e que as obriga, apesar dos protestos, num estado de degradação da condição humana. O quadro continua sendo até a atualidade, de escolarização precária, apesar dos tímidos programas assistencialistas e emergenciais do governo brasileiro neste campo ${ }^{10}$ (Programa Mão Amiga), programas esses que prometem "incluir, excluindo"; o crescimento dos maus-tratos, trabalho infantil invisível em alguns setores da produção urbana e rural, formal e informal, a violência doméstica, a exploração sexual, as mortes violentas de crianças e adolescentes, a desnutrição ${ }^{11}$, a mortalidade infantil. ${ }^{12}$

\section{Elementos teórico-metodológicos: os caminhos teórico-metodológicos trilhados}

Este estudo é inspirado nos pressupostos teórico-metodológicos da Crítica da Vida Cotidiana (1950) sustentada por Henri Lefebvre, principalmente, no que diz respeito à consideração dos aspectos macro e micro-sociológicos da vida cotidiana, a saber: pobreza (alienação, conformismo, exploração) e riqueza (emancipação, lutas sociais, resistência) da vida cotidiana. Além disso, baseia-se na obra de Agnes Heller (1994), a partir de seu conceito de Sociologia da Vida Cotidiana, compreendida em sua heterogeneidade universal, portanto, na dimensão evolutiva da totalidade (generalidades e particularidades) da sociedade.

Grossomodo, em termos de forma e conteúdo, as questões teórico-metodológicas foram sendo construídas a partir dos seguintes aspectos: a) a pesquisa de campo foi realizada nos Eventos-Campos, cujo lócus se constituíram, basicamente, da minha participação em eventos de natureza política promovidos por sindicatos, ONGs e movimentos sociais diversos: Tribunais Nacionais e Internacionais e Independentes Contra o Trabalho Infantil (Brasília, México e São Paulo) sob os auspícios do PTPartido dos Trabalhadores/4a. Internacional - O Trabalho, Marcha Global Contra o Trabalho Infantil (São Paulo Buenos Aires e Montevidéu) encontros de crianças e pais trabalhadores rurais/FETAPE)/CONTAG, encontros promovidos por ONGs (Save the

\footnotetext{
${ }^{10}$ Refiro-me ao Programa de Erradicação do Trabalho Infantil, do Governo Federal, cujo pano de fundo é o jargão Brasil Criança Cidadã: Programas de Proteção Integral - 7 aos 14 anos (Bolsa Escola). Este tipo de programa é uma adaptação do Programa Renda Mínima, cuja extensão atinge os Estados de Pernambuco, Sergipe, Mato Grosso do Sul e Rondônia. É, portanto, uma medida emergencial que inclui as crianças em escolas com instalações precárias e salários de miséria para os professores. Isto, quer dizer, a escola mostra a sua faceta paradoxal: promete incluir excluindo (Luft, 1997).

${ }^{11}$ Segundo o relatório Situação Mundial da Infância (UNICEF, 1999), nos países em desenvolvimento, a desnutrição atinge mais de 200 milhões de crianças menores de cinco anos. A desnutrição é um dos fatores responsáveis por mais de metade dos 12 milhões de mortes atuais de menores de cinco anos nos países em desenvolvimento.

${ }^{12}$ Cf. O Relatório A Infância Brasileira nos anos 90 (UNICEF, 1998).
} 
Children), visitas ocasionais aos engenhos e usinas de açúcar; b) a investigação foi, paulatinamente, sendo socializada no processo de construção ${ }^{13}$ com os sujeitos e as instâncias acadêmicas; c) a problemática, dada a sua emergência, complexidade e relevância social, exige uma continuidade e a realização de projetos futuros de pesquisa-ação junto aos movimentos sociais (ONGs, sindicatos); d) o caráter interdisciplinar com diversas áreas do conhecimento (sociologia do trabalho, sociologia rural, sociologia do açúcar, sociologia do lazer, sociologia da infância, economia, antropologia, psicologia social, psicologia do jogo, direito, história, medicina do trabalho, serviço social, comunicação e jornalismo e outras; e) a compreensão do método como caminho construído num processo de constante movimento e desenvolvimento, como orientação teórica, e não como produto acabado ou camisa de força; f) as relações sujeito-objeto no processo do conhecimento compreendidas como relações sociais de alteridade (Santos, 1977: 78); g) a valorização das vozes e representações das crianças, eivadas de crítica social e utopia, contidas em seus sonhos-desejados; h) a utilização de instrumentos de coleta de dados, compreendidas não apenas como meras técnicas, mas como teoria em atos (Bourdieu apud Thiollent, 1982) ou modos de abordar a realidade (Santos, 1991)0; i) a utilização de uma gama instrumentos de coleta de dados, considerando-os como elementos possíveis para a criação de um quadro de referência teórica (categorias, conceitos, temas, subtemas), tais como: fotografia, poesia, desenho, entrevista , observação, oficinas de jogos e brincadeiras e documentos diversos (cartas e bilhetes das crianças, folders, cartas, documentos institucionais e outros); j) a consideração nos seguintes aspectos: história da minha própria infância, a relação teoria e prática da minha atividade acadêmica, as reflexões teórico-metodológicas tecidas ao longo da minha atuação pedagógica e os problemas sociais de relevância pública; l) a concepção de história, compreendida como a medula do estudo social e uma permanente atualidade (Mills, 1982:156), consecutivamente, do presente, compreendido, como produção de historicidade.

Para descobrir os conceitos e categorias particulares da pesquisa, tais como: trabalho precoce, trabalho ajuda, lazer dos ricos e dos pobres, corpo produtivo e corpo brincante, exclusão social elou inclusão precária, envelhecimento precoce, foi necessário levar em consideração as relações da prática social da pesquisa com o quadro

\footnotetext{
${ }^{13}$ Durante todo o processo de construção e os resultados parciais da pesquisa campo foram publicados no Jornal Universitário da UFSC.
} 
de leis e categorias universais (luta de classes, trabalho, mercadoria, exploração, alienação) para, deste modo, poder investigar as realidades particulares, os conjuntos, as classes, as espécies, os conceitos e suas relações; e, tudo isso, a partir da experiência do contato com o conteúdo emergido das incursões na realidade investigada. Seguindo essa lógica, pode-se abstrair que as categorias advindas do fazer cotidiano da pesquisa, como, por exemplo, trabalho e lazer são conceitos que expressam entre si relações essenciais acerca da realidade: modos de ser, determinações da existência, aspectos ligados à cultura, à política, à educação, à economia (Lefebvre, 1975: 237).

Como se podem constatar, todas essas questões se constituíram, no processo de investigação, um norte para a análise dos elementos da vida cotidiana (trabalho e lúdico), orientando a busca de elementos inerentes à realidade: conceitos, categorias específicas, temas e subtemas, a partir das evidências ocultas e manifestas encontradas no real. Neste movimento foi possível captar as múltiplas determinações do fenômeno, cuja configuração empírico-teórica poderá anunciar os sinais de continuidade e descontinuidade, aparecimento e choque de contradições, saltos qualitativos e superação (Ibidem).

\section{Exploração do trabalho infantil: o que vale mais o número e ou o ser humano?}

Para melhor esclarecer os leitores sobre o problema da exploração do trabalho infantil, urge apresentar alguns dados estatísticos das diversas instituições que investigam a situação da criança e do jovem, tanto no Brasil quanto no mundo. No entanto, neste livro, esses dados não são valorizados, unicamente, pelo seu caráter numérico e quantitativo, principalmente, em virtude do trato com questões inerentes ao campo das investigações de aportes teórico-metodológicos qualitativo. Além disso, os diversos organismos internacionais que tratam dessa questão (OIT e UNICEF), alegam ter dificuldades em encontrar um método para mensurar com precisão o número de crianças exploradas nos diversos mundos do trabalho infantil no Brasil e no mundo.

Todo esse imbróglio institucional, no campo do quantativismo exarcebado, fortaleceu em mim a idéia de que o ser humano deve ontologicamente se impor acima do número e da racionalidade instrumental do cálculo.Digo isto porque grande parte dos economistas e cientistas sociais na atualidade ainda cometem este equívoco, ao agarrarse unicamente ao fetiche dos percentuais estatísticos, sem levar em conta os aspectos de 
ordem qualitativa como a subjetividade, a cultura, a sociabilidade, os desejos e a história dos sujeitos. Dito desta forma, o que está em jogo aqui não é só dimensão quantitativa de milhões de crianças e jovens à margem dos seus direitos e cidadania, mas o fato de que, se pensarmos qualitativamente as relações sociais, poderemos compreender que, se tratando de uma só criança ou um jovem, vivendo nessas circunstâncias - já se justificaria a emergência de estudos e políticas públicas para intervir e mudar esse quadro. Para mudar essa lógica formal, é preciso inverter o senso de proporção, tentando, antes de priorizar a mensuração, tentar avaliar qualitativamente as dimensões e as conseqüências para a humanidade de certos fenômenos sociais, mesmo que se trate de um só ser humano inserido em processos, episódios e eventos de desumaninação e opressão. Considerando o exposto, os dados que se seguem não pretendem apenas, usando a linguagem dos meramente estatísticos, conhecer o universo de fazer a amostragem (Mills, 1982:231), mas a partir de um outro ethos, refletir quantitativa e qualitativamente sobre o quanto temos para superar os séculos de destruição e precarização da situação da infância e juventude, expressos na história das políticas sociais de assistência a esses sujeitos.

Continuando nas pesquisas estatísticas dos organismos internacionais sobre a condição da infância empobrecida no mundo, os relatórios da UNESCO nos lembram que, na África, cerca de 1 milhão de crianças morrem a cada ano em conseqüência do serviço da dívida externa. Isto, não em decorrência de todo um conjunto de reformas, mas, sobretudo, pelos juros que seus países precisam pagar em termos de dívida externa. Além disso, estima-se que cerca de 11 milhões de crianças morrem em todo ano com doenças que poderiam ser tratadas facilmente e que não custaria mais do que alguns centavos. No entanto, os economistas informam que isso representaria uma interferência no sistema de mercado livre (Chomsky, 1997:108).

Quando se trata da relação entre dados estatísticos, políticas sociais, políticas do corpo, infância e juventude das classes populares ${ }^{14}$, pode-se constatar que a violência estrutural do capital, penaliza a classe trabalhadora com morte de milhões de crianças desnutridas em todo o planeta.No Brasil, por exemplo, estas crianças empobrecidas correspondem a 53\% das crianças brasileiras, das quais $19 \%$ vivem no Nordeste e $6 \%$ na região Norte, como indicam os dados do UNICEF. Aliás, um grande contingente

\footnotetext{
${ }^{14}$ Ver a esse respeito a publicação $A$ Infância Brasileira dos nos Anos 90/UNICEF,na qual há um extenso estudo sobre Renda e Pobreza das Crianças(Cap.II:20-40), chamando a atenção para o agravamento da distribuição de renda que afeta as famílias e as crianças.
} 
dessas crianças se assemelha às do sertão alagoano, cuja estrutura corporal é quase como um peso de um passarinho ${ }^{15}$.

Com respeito aos dados sobre a exploração do trabalho infantil em nível mundial, tanto os relatórios do UNICEF quanto da OIT apontam para a estimativa de 250 milhões de crianças trabalhando em todo o mundo. Já no Tribunal Internacional contra o Trabalho Infantil, realizado em São Paulo em 1999, houve a indicação de que seriam mais de 300 milhões de crianças e que no ano 2004, serão 400 milhões de trabalhadores e trabalhadoras infanto-juvenis, em conseqüência do crescente desemprego em todo o mundo ${ }^{16}$. No Brasil, de acordo com o relatório mais atual do próprio UNICEF, Situação Mundial da Infância 2000, aproximadamente 2,9 milhões de brasileiros, entre cinco e catorze anos, trabalham para reforçar a renda familiar. $\mathrm{O}$ índice de trabalhadores precoces aumenta para 5,7 milhões na faixa etária de dez a dezesseis $\operatorname{anos}^{17}$.

De um modo geral, o que chama a atenção é que os dados estatísticos, às vezes, parecem diminuir com o passar do tempo, talvez, em virtude da natureza emergencial e assistencialista das políticas emergenciais, fato este que se torna motivo de grande alarde e propaganda pelo governo brasileiro e da OIT. Em contrapartida, a esses resultados de marketing estatístico, levanto a hipótese de que se taxa de desemprego aumenta, então, deveria também subir, concomitantemente, a cifra de crianças trabalhando precocemente nos postos de trabalho dos adultos! Mas isso, por questões de método, não aparece nas estatísticas dos organismos nacionais e internacionais, mas sim e, muito pouco, nos discursos de algumas centrais sindicais.

O crescimento ou retração dos dados estatísticos tem a ver com a legislação vigente em cada país e as normas da OIT. Neste sentido, o ponto de vista da história da legislação sobre o trabalho infantil, o que se pode perceber é que há grandes avanços cartoriais até os dias de hoje, em especial, com o advento do Estatuto da Criança e do Adolescente, aprovado em $1990^{18}$. Em contraposição, há, de um lado, a partir das leis,

\footnotetext{
${ }^{15}$ Cf.documentário apresentado pela TV Cultura em Dezembro de 2002.

${ }^{16} \mathrm{O}$ UNICEF detectou recentemente, a inserção de crianças trabalhando nos lixões das pequenas, médias e grandes cidades. Além disso, cresce assustadoramente em todo o mundo, sobretudo na Ásia, o trabalho doméstico infantil, atividade na qual predominantemente as mulheres e meninas suportam cargas e são submetidas a tratamentos que refletem seu status desigual. Além do mais elas são tratadas como invisíveis, como se não existissem (Ibidem); crescem também de outras formas de trabalho infantil urbano (borracharias, supermercados, etc.) e rural (olarias, casas de farinha, etc.).

${ }^{17} \mathrm{http}: / /$ www.unicef.org.br/

${ }^{18}$ Ver as críticas sobre as piores formas em Liebel (2003). Cf. O Comitê Catarinense Contra o Trabalho Infantil (mimeo, 1999) a legislação sobre o trabalho infantil pode ser
} 
uma crescente consciência social acerca dos prejuízos da exploração do trabalho precoce para a construção da identidade da criança, entre eles a supressão do lúdico.De outro lado prevalece ainda, com bastante força no patronato, principalmente, no âmbito dos pequenos empresários, a tendência à exploração invisível do trabalho de crianças e jovens, relegando a estes uma cidadania abstrata que só exercida no ponto de vista cartorial e legal.

Como já destaquei no início do texto, as estatísticas ainda são usadas de forma meramente quantitativa por alguns organismos nacionais e internacionais, principalmente, quando se trata de exploração da força humana do trabalho infantil e,conseqüentemente, da sua relação com desemprego dos adultos. Há, no entanto, uma dimensão quantitativa-qualitativa que não dá para fazer vistas grossas quando se trata da relação entre desemprego estrutural e a utilização do braço infantil no mundo da exploração capitalista. Trata-se do crescente aumento da exploração do trabalho infantil em todo o mundo em virtude do desemprego dos trabalhadores adultos, cuja cifra, segundo a OIT no final de 1999 é de cerca 1 bilhão e 200 milhões de pessoas desempregadas e imersas no mundo do trabalho precário. Esses trabalhadores são considerados supérfluos e descartáveis para o capital (FORRESTER, 1997). Neste sentido, poderá ser cada vez maior o contingente de crianças condenadas a assumir precocemente as responsabilidades do provimento total ou parcial da renda familiar. Sendo assim, o que se vê, no limiar da conjuntura da globalização neoliberal, cujas conseqüências daí resultantes, incidem sobre a saúde e a qualidade de vida dos trabalhadores, sobre a organização do seu tempo, do seu espaço e dos seus estilos de vida - enfim, sobre a construção da identidade nos diferentes planos e dimensões da vida social, a saber: trabalho, família, vida existencial, sindicados, partidos e outras. Portanto, esta crescente instabilidade econômica e flexibilização, geram destruição e

delineada da seguinte maneira: a) em nível internacional e b) em nível nacional. Em nível internacional a OIT - Organização Internacional do Trabalho, através da Convenção no. 05 de 1919, proibia o trabalho até 14 anos em estabelecimentos industriais: a Convenção no. 138 de 1973, previu que os Estados membros, especificassem uma idade mínima de admissão ao emprego, não inferior à idade na qual ocorre o término da escolaridade obrigatória, ou seja, 15 anos; a Convenção no. 182 de 1998, pretende erradicar imediatamente apenas as piores formas de trabalho infantil, as quais referem-se aos delitos penais, ou seja, formas de exploração já elencadas em nossa legislação, a saber: prostituição, escravidão, pornografia, tráfico de drogas. (Portanto, na Convenção 182 apenas o item d) caracteriza trabalho e nele podemos incluir todo e qualquer trabalho executado por crianças, pois todos representam uma ameaça à saúde, segurança e moralidade (Comitê Catarinense independente Contra o Trabalho Infantil, 2000, mimeo). 
precarização dos postos de trabalho dos $\operatorname{adultos}^{19}$, impulsionando, deste modo, a ascendente superexploração de crianças e jovens.Para ilustrar tudo isso, pode-se tomar como referência o quadro de miséria cotidiana dos países periféricos, onde o caminho do paraíso da flexibilização é algo parecido com o inferno já vivenciado pelo gênero humano nos idos do século XIX: na Índia, por exemplo, em 1993 foi invadida uma fábrica de tapetes para libertar 128 crianças menores de 13 anos, trabalhando de 12 a 16 horas, 7 dias por semana, 52 semanas por ano (Coggiola,1995:159).

A dinâmica de destruição e exclusão social patrocinada pelos gestores do capital internacional como o FMI e o Banco Mundial, atinge tanto crianças e jovens, quanto grande contingente da classe trabalhadora constituída de adultos e velhos. Atinge os trabalhadores assalariados, quer dizer, os que ainda estão nos seus postos de trabalho, como também os chamados incluídos precários, digo, aqueles que vivem a violência do desemprego e os dilemas da precariedade dos sub-empregos da economia informal quanto aqueles desempregados quase que perenes. Portanto, o suposto tempo livre é um tempo de escassez, de tensões, medos e incertezas, tempo que aprisiona e oprime os sujeitos aos esquemas individualistas da máxima liberal do salve-se quem puder e do cada um por si e Deus por todos e da lógica da liberalização do mercado. Nesta perspectiva, a possível supressão do usufruto do lazer para a vivência da cultura lúdica dos trabalhadores sub-empregados, precarizados ou desempregados, pode ser refletida à luz da seguinte afirmativa de Emir Sader rico tem lazer, pobre se diverte como pode! ${ }^{20}$.

Todo o trajeto realizado na concepção teórico-medológica deste estudo, leva em consideração a nova divisão internacional do trabalho, fundamentada na globalização da produção construída pelas empresas multinacionais, paulatinamente convertidas em atores centrais da nova economia mundial. Esta dimensão da criação destrutiva da nova economia mundial (Souza Santos, 2002:29-31), também cognominada de globalização econômica neoliberal, cria impactos e conseqüências sob a construção da subjetividade e identidade individual, social e coletiva dos trabalhadores, fundamentalmente, no ponto de vista dos determinantes éticos, econômicos, culturais, enfim, das relações sociais e históricas.Essas determinações tendem a se configurar como (des) sociabilização da vida cotidiana,a partir dos seguintes aspectos: destruições da força humana de trabalho, coletividade; direitos dos trabalhadores, sindicatos, associações, cooperativas, família,

\footnotetext{
${ }^{19}$ Refiro-me diversas formas de precarização laboral, tais como: Call Centers, teletrabalho, trabalho em casa, enfim, as diversas atividades Par-time sem contrato permanente de trabalho.

${ }^{20}$ Expressão proferida durante O Congresso Mundial de Lazer em São Paulo (1999).
} 
meio ambiente, infância, juventude, velhice (Bourdieu, 1999; Kurz, 1996; Antunes, 1995; Souza Santos, 2002 e outros).

Todo esse processo destrutivo da força humana de trabalho resulta na exploração de milhões de crianças, em virtude de milhões de pais e mães serem jogados no desemprego, na incerteza e na miséria. Quanto a essa questão, pode se dizer que se forma, assim, um círculo vicioso no qual, de um lado, as crianças submetem-se a um salário de miséria, aumentando o desemprego dos adultos e baixando os seus salários; e, de outro lado, o desemprego dos adultos tende a fazer da exploração do trabalho infantil a única possibilidade para aumentar a pífia renda ou ausência na estrutura familiar.Em razão de tudo isso, as crianças empobrecidas são compreendidas, e por isso mesmo,utilizadas como força de trabalho não organizada e mais dócil, tornam-se assim,uma arma nas mãos do capital para pressionar e solapar os postos de trabalho do conjunto dos trabalhadores adultos assalariados (Chossudovsky, 1998; Galeano, 1999; Pochmann, 1999).

Mesmo que os dados dos organismos oficiais e internacionais possam ser questionados em sua legitimidade e confiabilidade, como o faz Libel (2003) com os dados da "erradicação do trabalho infantil", ainda assim, penso ser de suma importância realizar análises qualitativas do Banco Mundial. Senão vejamos: segundo dados deste organismo internacional: dos 6 bilhões de habitantes do mundo, 2,8 bilhões sobrevivem com renda mensal inferior a 60 dólares, e 1,2 bilhão com menos de 30 dólares; mais de 1,5 bilhões de pessoas não têm acesso a água potável e cerca de 125 milhões de crianças em idade escolar não freqüentam escolas (Christo, 2001:19). Além desses dados, quando está em debate as políticas do corpo, necessário se faz, voltar o olhar para os dados do IDH (Índice de Desenvolvimento Humano) ${ }^{21}$, cuja metodologia privilegia a síntese de três dimensões: longevidade, educação e renda. Neste sentido, os índices apresentados, a partir do Relatório de Desenvolvimento Humano (RDH) de 2006, do Programa das Nações Unidas para o Desenvolvimento (PNUD), nos mostram que o Brasil, no que refere aos índices de pobreza, reduziu pela metade (52\%) o número de pessoas que recebem 1 dólar por dia. De acordo com IDH, o Brasil cumpre 10 anos antes Objetivos de Desenvolvimento do Milênio. Esse mesmo relatório mostra, que quase 2 milhões de crianças morrem todos os dias por falta de um copo de água limpa. Esses números são a radiografia das condições objetivas de vida da classe trabalhadora

\footnotetext{
${ }^{21}$ Quanto a esses dados ver o Relatório de Desenvolvimento Humano 2002/PNUD. Site: http://www.pnud.org.br/home/
} 
empobrecida brasileira. Mesmo com esses dados otimistas, não se pode confiar na objetividade das estatísticas - mas sim buscar metodologias qualitativas que possam dar conta da essência dos problemas sociais, econômicos, políticos e culturais. Assim como os dados da OIT, UNICEF, Governo Federal e os índices do IDH não podem escamotear as condições de miséria em que a classe trabalhadora empobrecida pelas políticas sociais, tanto na zona rural, quanto urbana, onde proliferam: fome, analfabetismo, desemprego, subemprego, prostituição, violência, meio ambiente degenerado, falta de saneamento básico, falta de hospitais, renda per capita muito baixa, nível de expectativa de vida cada vez baixo - em suma uma.

No que tange as interfaces entre exploração do trabalho infantil e políticas do corpo urge lembrar que são, 250 milhões de crianças em todo o mundo. Quanto a esse respeito, à guisa de ilustração, as estatísticas indicam que há mais meninos que meninas trabalhando, em média cerca de três meninos para cada menina. Das regiões em desenvolvimento no mundo, a África tem o maior número de participação das meninas (37\%). Estes dados, no entanto, devem servir apenas como motivação para as análises qualitativas, considerando que, com freqüência, as pesquisas estatísticas calculam por baixo a quantidade de meninas que trabalham, pois não costumam levar em conta as atividades não-remuneradas, inclusive nas empresas familiares. Quanto a essa questão, convém lembrar que, o trabalho doméstico de natureza não-econômica, em tempo integral, também é realizado em maior escala pelas meninas, muitas delas com idade entre oito e doze anos de idade. Elas são responsáveis, por exemplo, pelos cuidados com a casa de seus próprios pais, para permitir que estes saiam para trabalhar (Enciclopédia do Mundo Contemporâneo, 2000:51).

Retomando á questão da legitimidade dos dados da OIT sobre o "trabalho infantil”, há, quanto a esse respeito, controvérsias sobre verossimilhança dos dados acerca das categorias "trabalho infantil tolerável", "trabalho infantil intolerável", "piores formas de trabalho infantil", como já mencionamos anteriormente (LIEBEL, 2003). Isto significa dizer que, para além dessas categorias questionáveis, também se impõe o questionamento sobre a falta de provas empíricas. Há, neste sentido, dúvidas sobre as fontes e os métodos de medição, sobre os quais estão fundamentados os dados indicados e, além do mais, quais são os problemas práticos que surgiram na determinação do número de crianças trabalhadoras em nível mundial, segundo critérios uniformes. Posto isto, analisando de forma mais rigorosa, percebe-se os dados em questão, se baseiam em fontes muito diferentes que, por sua vez, se fundamentam em 
conceitos estatísticos não são comparáveis. Mesmo assim, a base de dados é muito escassa, ou seja, as cifras quanto ao número de "trabalhadores infantis" para o ano de 2004, por exemplo, estão baseadas somente em dados de 31países e, na maioria do ano 2000 (LIEBEL, 2003) ${ }^{22}$.

O informe da OIT afirma que o número de "trabalhadores infantis, diminui, sobretudo, na América Latina e no Caribe, no transcurso de quatro anos, que haveria se registrado uma redução de dois terços (parágrafo 29). Nestes termos, diante da audácia de afirmações como essas, as e os conhecedores latino-americanos da situação acerca do trabalho infantil, não deixam de ficar assombrados e estarrecidos (LIEBEL, 2003). Quanto a esse respeito, podem ser dados vários exemplos: segundo um artigo do jornal Paraguay, em mayo de 2006, o escritório local do UNICEF, sinalizou que o número de “crianças economicamente ativas", aumentou em aproximadamente 56.500 nos últimos anos. Da mesma forma, também o Ministério do Trabalho argentino, realizou uma enquête, de cujos resultados concluiu que, em nível nacional, o trabalho infantil "aumentou de maneira alarmante". Em contrapartida, um informe do Escritório Regional Andino de Terre des Hommes, sugere que os dados do informe da OIT, foram manipulados para que suas atividades de luta contra o trabalho infantil aparecessem de forma mais positiva (grifos meus).

Outros exemplos seguem-se: em 1999 os relatórios do UNICEF e OIT apontavam para os números de aproximadamente 250 milhões de crianças trabalhando em todo o mundo, ao passo que o Tribunal Internacional contra o Trabalho Infantil indicava na época, a cifra de mais de 300 milhões, argumentando, inclusive, que no ano 2004, serão 400 milhões de crianças enquanto força humana barata de trabalho, em conseqüência do crescente desemprego em todo o mundo. Também, quando iniciei a pesquisa, os dados do Centro Josué de Castro, datados de 1995, indicavam que havia 50.000 crianças na faixa de 7 a 14 anos trabalhando nos canaviais de Pernambuco. Hoje, passados 12 anos, há a controvérsias de que, supostamente, não existe mais esse número de crianças trabalhando, considerando os programas de inclusão precária, isto é, de caráter emergencial e assistencialista do Governo.

\footnotetext{
${ }^{22}$ Los datos en los que se fundamenta el informe tampoco permiten determinar si la magnitud del trabajo infantil realmente ha disminuido entre los años 2000 y 2004. Primero, sólo se tiene datos de 17 países y referentes a dos años diferentes. En algunos casos, esta información abarca un período de tiempo tan corto que es totalmente insuficiente para deducir o identificar alguna tendencia de ella. Por ejemplo, las estadísticas para Kenia se refieren a los años 1999 y 2000. Segundo, en el caso de la India, por ejemplo, sólo se tiene datos de los años 1994 y 1999/2000, lo que, obviamente, no permite sacar ninguna conclusión para los años 2000 a 2004. Los datos para Brasil, que se refieren a los años 1998 y 2003, son los únicos que se acercan al período del 2000 al 2004.
} 
O Programa Mão Amiga ${ }^{23}$ (Criança Cidadã), hoje Bolsa Família ${ }^{24}$, antes restrito a apenas 13 municípios, hoje cobre uma faixa de aproximadamente 20, atendendo uma média de 68 mil crianças na faixa etária de 7 a 14 anos. ${ }^{25}$ Isto significa dizer que, de acordo com os dados quantitativos, supostamente não existem mais crianças trabalhando na palha da cana. Mesmo que esta nova configuração estatística seja confirmada, impõe-se considerar, no ponto de vista qualitativo, o fato desses programas serem apenas compostos de medidas emergenciais, não oferecendo, portanto, paralelamente, programas estruturadores, nem garantias de que as crianças não voltem clandestinamente ao trabalho. Além disso, o Mão Amiga apresenta limites de alcance efetivo às populações às quais atende, devido aos drásticos cortes implementados pelo Governo Federal. Assim é que, de um lado reduziu o valor da bolsa e, de outro, contraditoriamente, aumentou o número de municípios beneficiados. As reflexões acerca das estatísticas devem ser, no entanto, relativizada, uma vez que muitas das crianças que estavam sendo beneficiadas pelo Programa Mão Amiga jamais trabalharam, muito embora, igualmente empobrecidas; e outras que trabalhavam do trabalho pesado da cana, que ficaram de fora, excluídas deste tipo de programa, eivado de equívocos e contradições Além disso, existem rumores não comprovados da participação das na perspectiva da clandestinidade, pouco susceptível, às vezes, de fiscalização por parte das autoridades e da própria sociedade civil organizada. É preciso, portanto, investigar com maior profundidade os dados e discursos otimistas da OIT, Governo Federal, ONG's e da mídia, que, ao mesmo tempo em que celebram erradicação do trabalho infantil, através taxas estatísticas, terminam por contribuir para a perpetuar esse tipo de exploração e, consequentemente, a reproduzir a lógica do capitalismo.

Toda essa oscilação ou dança dos números estatísticos, se deve a uma harmonização dos métodos de medição em coordenação com as instâncias

\footnotetext{
${ }^{23}$ No atual Governo de Luís Inácio Lula da Silva e no seu primeiro mandato este programa, que antes estava vinculado ao Programa "Bolsa Escola"no Governo de Fernando Henrique Cardoso - atualmente foi convertido no "programa Bolsa Família".

24 O Programa Bolsa Família (PBF) é um programa de transferência direta de renda com condicionalidades que beneficia famílias pobres (com renda mensal por pessoa de $\mathrm{R} \$ 60,01$ a $\mathrm{R} \$ 120,00$ ) e extremamente pobres (com renda mensal por pessoal de até R $\$ 60,00$ ). O Bolsa Família [...] pauta-se na articulação de três dimensões essenciais à superação da fome e da pobreza:promoção do alívio imediato da pobreza, por meio da transferência direta de renda à família; reforço ao exercício de direitos sociais básicos nas áreas de Saúde e Educação, por meio do cumprimentos das condicionalidades, o que contribui para que as famílias consigam romper o ciclo da pobreza entre gerações Cf. Site http://www.mds.gov.br/bolsafamilia/

$\frac{25}{25}$ Esses dados são relativos ao segundo mandato do governo de Fernando Henrique Cardoso (1998/2003).
} 
internacionais. Para além deste tipo de procedimento duvidoso, na avaliação das taxas exploração do trabalho de crianças, pode-se exemplificar, a partir da experiência de Ongs e movimentos de crianças trabalhadoras, as quais contradizem as boas notícias de progresso em prol da diminuição dos índices do trabalho infantil, grande parte delas, carecendo de credibilidade, provas empíricas e de força comprobatória analítica. Todo esse projeto de ardiloso de erradicação, desenvolvido pela OIT-IPEC, é, portanto, respaldado com a denúncia vazia e abstrata sobre os efeitos que tem os processos de da globalização neoliberal e das estratégias político-econômicas como as liberalizações, as desregulamentações e as privatizações sob o trabalho de meninos e meninas. Diante dessas questões, de caráter político-econômico a OIT, se posiciona de forma bastante nebulosa, apresentando como alternativa, apenas uma suposta vontade para uma globalização justa, sem, todavia apontar com clareza e objetividade para os caminhos em direção às transformações sociais em nível planetário, melhor dizendo, para a construção de uma sociedade, no dizer de Mésáros (1981) para além do capital (LIEBEL ${ }^{26}$, 2003; SILVA, 2003).

\section{Trabalho infantil ou exploração do trabalho infantil? Eis a questão!}

$\mathrm{Na}$ epígrafe de abertura deste texto, Viviane Forrester, ao fazer críticas ao projeto societário neoliberal, adverte para a gravidade desses tempos difíceis sob a égide do capital, para os trabalhadores de todo o mundo, ao dizer: “(...) ao ver que, para além da exploração dos homens, havia algo ainda pior: a ausência de qualquer exploração como deixar de dizer que, não sendo sequer exploráveis, nem sequer necessárias à exploração, ela própria inútil”. Tal afirmação revela na essência de seu conteúdo, isto é, as facetas contraditórias da exploração. Após engendrar a sujeição e a dominação das relações sociais, através do trabalho alheio para acumulação de riquezas - agora cumpre com sua missão iníqua, que é a transformar os seres sociais, anteriormente submissos e hoje incluídos à margem da produção da vida material - incluindo-os á margem do trabalho e, consecutivamente, abandonando-os - mas ao mesmo tempo - (re) escravizando-os!

A questão colocada por Forrester (1997), me parece ser o grande dilema e tragédia ontológica da modernidade. Ou seja, o trabalho alienado, que, até então,

\footnotetext{
${ }^{26}$ Críticas do Deutsche NRO-Forum Kinderabeit" ("Fórum de ONGs alemàes sobre o Trabalho Infantil").
} 
explorava o trabalhador através do trabalho perene. O trabalhador era claramente explorado e, por sua vez que produzia mais-valias que eram apropriadas pelos capitalistas e que não lhe retribuía com a riqueza produzida por seu trabalho. A exploração, que traz em seu espectro a alienação econômica, isto é, aquela ligada diretamente à exploração do trabalho "alheio", vinculada à transferência de riqueza daqueles que criam para os que "explorem" esse trabalho através de distintas formas de capital-terra, fábricas, minas, transporte, comércio, serviços etc. (SADER, p.65, 2000). Porém, na atualidade o que vem tendo efeitos dramáticos sob a subjetividade e a saúde coletiva dos trabalhadores - são, justamente, as novas formas de exploração e, no caso do objeto de estudo aqui em pauta, a exploração do trabalho infantil. Obrigados regras de mercado do capital, os trabalhadores hoje em dia, têm que se submeter a um tipo de trabalho escravo, tão perverso quanto o trabalho alienado nos moldes tayloristafordista, enfim, a um tipo de exploração que, como bem disse Forrester (1997) que empresta á vida cotidiana dos homens e mulheres, crianças e jovens - o emblema de sociedade de escravos.

No âmbito deste processo destrutivo, encontra-se o fenômeno do trabalho infantil, ou melhor, a exploração do trabalho infantil. Trata-se de problemática bastante complexa, carregada de mitos e equívocos. Ela está imersa num enorme emaranhado de senso-comum, que se encontra ainda arraigado, tanto na academia, quanto das instituições e órgãos oficiais, assim como, na mídia e na população em geral. Considerando que este livro busca trazer para o debate as relações entre infância, educação e políticas públicas, este texto visa, provisoriamente, a levantar questionamentos e contribuir para o debate sobre a questão que subjaz o título acima formulado em forma de pergunta trabalho infantil ou exploração do trabalho infantil? Esta questão é de tamanha pertinência, pois, tanto a literatura acadêmica, salvo raras exceções, quanto os documentos oficiais do governo, da OIT (dados estatísticos) e nãogovernamentais (terceiro setor), privilegiam a expressão trabalho infantil, ao invés de exploração do trabalho infantil, como veremos adiante. Deste modo, inauguram uma certa confusão conceitual, etimológica, epistemológica, ontológica e ideológica, a qual culmina por incidir e influenciar à produção de políticas públicas ${ }^{27}$.

Para início de conversa, a exploração do trabalho infantil, na trilha dos mais de dois séculos de capitalismo, do século XIX ao XXI, desde o processo do industrialismo

\footnotetext{
${ }^{27}$ As reflexões suscitadas neste texto, já foram em parte, abordadas por Silva (2003) em seu livro Trama doce-amarga: (Exploração do) Trabalho Infantil e Cultura Lúdica.
} 
insurgente até os dias atuais, chamado capitalismo neoliberal, só foi capaz de criar destruição e violência para os trabalhadores e suas famílias, sobretudo, para crianças, mulheres e jovens, não superando, assim, a barbárie por ele mesmo forjada. Essas questões supramencionadas podem ser constatadas na literatura que trata da historiografia da classe trabalhadora, por exemplo: A situação da Classe Trabalhadora na Inglaterra (Engels, 1985), diversos textos de Marx e Engels como Manifesto do Partido Comunista (1998), Germinal (ZOLA, 1972), Educação Saber, Produção em Marx e Engels (NOGUEIRA, 1990). Nesta última obra, a autora analisa a exploração do trabalho infantil e feminino com base nos clássicos como $O$ Capital e a Situação da Classe Operária na Inglaterra. Em relação à produção a respeito, há também as obras do grande escritor e romancista inglês Charles Dickens: Oliver Twist (1938), Tempos difíceis (1812-1827) e a Casa Soturna. Em Tempos Dificeis, por exemplo, o autor relata como, no final do século XVII, no âmbito do trabalho fabril, no Reino Unido, crianças a partir dos seis anos de idade, ingressavam nas fábricas como aprendizes, com extensas jornadas de trabalho de até 16 horas por dia, no ambiente insalubre do chão da fábrica. Com essas produções literárias o autor ajudou a sensibilizar a opinião pública da época, utilizando como denúncia a sua própria experiência como ex-trabalhador infantil explorado.

Ao levar-se em consideração a história da classe trabalhadora, pode-se inferir que o processo de exploração do trabalho de crianças e jovens, mesmo que se tenha produzido bastante sobre esta problemática e considerando os escritos de Engels e Marx, seus interlocutores e outros autores, parece inverossímil que continue até hoje a saga dos filhos e filhas da classe trabalhadora empobrecida, imersa na exploração, na mais absoluta miséria ou nas teias da inclusão precária do assistencialismo, clientelismo e filantropismo. Com efeito, essas têm sido até então, as saídas políticas encontradas pelos governos dos países periféricos de industrialização intermediária e subordinada, portanto, dependentes do capital internacional para, de forma ideológica, cínica e perversa, proporcionar cidadania às crianças e jovens e, o que é mais iníquo, a promessa neoliberal de erradicar os diversos mundos do trabalho infantil, ou melhor, da exploração do trabalho infantil (zona rural: cana-de-açúcar, sisal, algodão, casa de farinha, pedreiras, olaria, e outros; zona urbana: borracharias, olarias, oficinas, comércio em geral, trabalho infantil feminino doméstico ${ }^{28}$ e outros), sem, contudo,

\footnotetext{
${ }^{28}$ Ver a esse respeito Silva (2002).
} 
erradicar a exploração dos trabalhadores adultos. Pelo exposto, pode-se abstrair que este problema social, secularmente engendrado pelo capital, está imerso no mundo do trabalho da lógica neoliberal da pós-modernidade, lógica esta, aqui considerada como uma fase do capitalismo na contemporaneidade, na qual a produção em massa de mercadorias padronizadas e as formas de trabalho a elas associadas foram substituídas pela flexibilização do trabalho.Aliadas a essa questão estão outras problemáticas que apontam para a multidimensionalidade da vigência do trabalho, em nível planetário, tais como: trabalho e desemprego, trabalho e precarização, trabalho e gênero, trabalho e etnia, trabalho e nacionalidade, trabalho e recorte geracional, trabalho e imaterialidade, trabalho e (des) qualificação e outras (KURZ, 2000:8-9). Essas transformações do mundo do trabalho se materializam no cotidiano dos trabalhadores adultos, sob a forma de desemprego, precarização das novas formas de produção e relações de trabalho. Com efeito, essa flexibilização vem, cada vez menos, empregando trabalhadores em tempo integral, isto é, a força de trabalho economicamente ativa que, diuturnamente, é solapada em seus direitos. Neste sentido, percebe-se como o capital é incapaz de realizar sua autovalorização sem se utilizar, de algum modo, do trabalho humano à medida que essa lógica estrutural possui em seu âmago a marca destrutiva, obrigando o ser social que trabalha ou a-classe-que-vive-do-trabalho e os aptos-para-o-trabalhomais-que-não-trabalham (CASTEL, 1991), a vivenciar seu cotidiano entre a violência do trabalho, a violência da precarização e a violência ainda mais grave do desemprego (ANTUNES, 2001:17-28). Na seara deste quadro de exclusão e violência, encontra-se a perversão do trabalho infantil, expressão cunhada por Neves (1999), isto é, a inclusão precoce e criminosa de crianças no mercado de trabalho, especialmente, nos países de industrialização intermediária e subordinada, como por exemplo, nos países asiáticos, latino-americanos e outros, aonde vêm se deteriorando prematuramente a força humana de trabalho das crianças e jovens, através da exploração invisível e, às vezes, do trabalho e da informalidade do mundo do trabalho.

A exploração do trabalho infantil, considerando a perspectiva da acumulação flexível inerente à Globalização e, consecutivamente à reestruturação produtiva do mundo do trabalho, trazem consigo, as conseqüências e impactos dos Planos de Ajuste Estrutural ou cardápios do FMI (CHOSSUDOVSKY, 1999) e Banco Mundial sobre as políticas sociais. Estas, por sua vez, vem se constituindo em meros programas de cunho assistencialista, clientelista, filantrópico, emergencial e geradoras de desemprego dos trabalhadores adultos e, consecutivamente, a exploração do trabalho das crianças. Estas 
políticas, em razão do caráter provisório delas, terminam por serem vetores de inclusão temporária e precária nas zonas urbanas e rurais.

Em síntese, o que está em destaque e que causa indignação dos movimentos sociais e sindicais, são as políticas aplicadas pelas instituições financeiras internacionais e governos, os quais visam à desregulamentação do trabalho, à flexibilização, à individualização do contrato de trabalho, dos horários e dos salários, a privatização da educação, dos sistemas de saúde e dos serviços públicos.

Como mencionei no início deste texto, um dos objetivos deste trabalho é também, refletir, de maneira crítica, sobre fenômeno da exploração do trabalho infantil e, não simplesmente, o que se ouve no senso-comum, do trabalho infantil. No entanto, considero fundamental estabelecer essa distinção, pois a exploração do trabalho se circunscreve na perspectiva da alienação e do estranhamento ${ }^{29}$. Esta máxima do capital resulta numa relação alheia do sujeito com objeto (trabalho), coisificando-o, por conseguinte, transformando, aviltando, degradando os homens e o produto do labor em mercadorias. Desse modo, desumaniza o ser social frente ao objeto, devido a sua imersão numa relação social fundada na propriedade privada e no dinheiro, constituindo-se na abstração da natureza específica e pessoal (ANTUNES, 1995:131). Isso significa dizer que o trabalho alienado, ao arrancar o objeto da sua produção, arranca-lhe a sua vida genérica, a sua objetividade genérica efetivamente real $e$ transforma a sua vantagem ante o animal na desvantagem de lhe ter tirado o seu corpo inorgânico, a natureza (MARX, 1978:147). Nessa perspectiva teórica, a exploração do trabalho infantil pode ser compreendida, inserida na compreensão do trabalho humano em sua dimensão abstrata, ou seja, as crianças são tratadas enquanto mercadorias geradoras de valor (valor de troca), através da produção voltada para o mundo das mercadorias, enfim da valorização e perpetuação do capital.

Quando se fala simplesmente em trabalho infantil, pode-se confundi-lo com qualquer tipo de trabalho de crianças, como por exemplo, o trabalho como princípio educativo. Nesse sentido, os princípios axiológicos e teleológicos, do ponto de vista dos pressupostos da teoria marxista, prevêem a relação real entre ensino e trabalho, trabalho

29 Segundo Antunes (1995: 132) a expressão trabalho estranhado (die Entfremdete Arbeit) ou estranhamento (Entfremdung) é diferente de alienação (Entäusserung), pois, enquanto esta última é um aspecto ineliminável de toda objetivação, o estranhamento refere-se à existência de barreiras sociais que se opõem ao desenvolvimento da personalidade humana. (Para Silveira citado por Antunes (1992) a Alienação (Entäusserung refere-se a alguma forma de perda, de privação, por parte de um sujeito e o Estranhamento (Entfremdung) um alheamento que) implicando a automização de um poder hostil), que se situa do lado do objeto, ainda que seja referido a um sujeito (Revista Resgate, Centro de Memória/UNICAMP, no. 04 1992). 
manual e intelectual, visando à formação unilateral. Esta devendo substituir a formação unilateral das crianças e jovem, tornando-os aptos para alternar as suas atividades de modo a satisfazer tanto as exigências da sociedade quanto as suas inclinações pessoais (MANACORDA, 1991:18). Essas considerações são fulcrais, considerando que há um senso-comum a respeito que quase sempre generaliza e banaliza a expressão trabalho infantil, omitindo o caráter de classe aí contido, além de fazer vistas grossas ao conteúdo da categoria da exploração, do alienus. Ora, em que resulta toda essa confusão de caráter ideológico e epistemológico? Resulta que toda essa polêmica, ao gerar dúvidas e equívocos, naturalizando o fenômeno da exploração do trabalho infantil, termina com esse fato, por trazer conseqüências epistemológicas e políticas, à medida que mitigam as críticas e as lutas sociais contra o anacronismo destrutivo do modo de produção capitalista. Assim, para complementar esse raciocínio, a simples expressão trabalho infantil, deve ser reformulada, visando ao seu entendimento para trabalho infantil remunerado, realizado sob condições vis ou penosas por crianças $e$ adolescentes, por isso mesmo interditado pela legislação (NEVES, 1999:10), mesmo que esta expressão não inclua em suas entrelinhas a categoria da exploração.

Outro ponto importante de ser abordado é sobre necessidade de tal diferenciação ser ocultada em grande parte dos documentos do UNICEF. Em seu Relatório Situação Mundial da Infância 2003, no qual está implícita a opção pela não-radicalização epistemológica da problemática da exploração do trabalho infantil, limita-se em denunciar ou apenas informar sobre os maus-tratos propiciados por todo o tipo de exploração contra crianças, sem, contudo, problematizar sobre os tipos de exploração e as conseqüências para a construção da subjetividade e cidadania infantil. Com efeito, os dados estatísticos, destacando a exploração do trabalho infantil, são colocados de forma subrepícia, por este organismo defensor das causas infanto-juvenis, no âmbito da seguinte simplificação do problema: crianças exploradas por adultos. Tal afirmação, além de nomear o capitalismo como o gestor por todo esse processo histórico de exploração do trabalho de crianças, considera-o culpado pelos riscos, causadores dos efeitos ameaçadores para o desenvolvimento infantil deste tipo de exploração na sociedade adulta e no comportamento irresponsável dos adultos, ao colocar neste âmbito o tráfico de crianças para o trabalho escravo e o recrutamento forçado de crianças como soldados para as guerras. Agindo dessa forma, a UNICEF presta um desserviço em prol do desocultamento deste fenômeno, corroborando para a manutenção do status-quo e a confusão epistemológica/etimológica entre os termos 
trabalho infantil/exploração do trabalho infantil. Dito dessa forma, não seria nenhum exagero admitir que a repercussão dessa confusão conceitual e ideológica possa incidir sobre a produção de políticas sociais, supostamente públicas, cujos programas e ações governamentais ditos de cidadania e inclusão social, na maioria das vezes, estão impregnadas de uma lógica precária, emergencial, clientelista e até filantrópica.

No que se refere à luta pela "erradicação do trabalho infantil”, pode-se ainda trazer para o debate em torno das ações da OIT-Organização Internacional do Trabalho $^{30}$, algumas idéias do texto de Manfred Liebel “¿Historia de éxito o de desorientación? El nuevo informe de la OIT sobre el trabajo infantil"31. Neste texto o autor, critica a OIT em seu “informe global sobre o Trabalho Infantil”. Diz que ela quiz dar um golpe maior" e que, "muito orgulhosamente e fazendo alarde de seus supostos êxitos", conseguiu anunciar e fazer crer que, o movimento mundial de luta contra o trabalho infantil instituído por ela própria, tivesse conseguido o seu anunciado êxito, ou seja, a eliminação do trabalho infantil. Para tanto, ainda hoje, a OIT insiste na idéia de que o crescimento econômico e a implementação da escolaridade obrigatória, se constituem numa espécie de "formula mágica" que afastaria as crianças da vida laboral e das ruas e colocando-as na escola (Liebel, 2003; SILVA, 2003).

$\mathrm{Na}$ esteira dessa reflexão, urge destacar, em contrapartida às posições do UNICEF, que, a exploração do trabalho infantil, fruto da ação destrutiva do capitalismo neoliberal, faz parte do processo de acumulação flexível da globalização da economia e, consecutivamente, da reestruturação produtiva do mundo do trabalho. Todo esse processo é consubstanciado pelos impactos e repercussões sob as políticas sociais dos países emergentes, através das políticas e planos de ajuste estrutural ou cardápios impostos pelo FMI e Banco Mundial. Desse modo, as políticas sociais do governo brasileiro apontam como saída à promessa de erradicação da miséria e, conseqüentemente, da exploração do trabalho infantil, através da miséria dos programas

\footnotetext{
${ }^{30}$ A iniciativa del entonces Ministro de Trabajo alemán, Norbert Blüm, la OIT creó, en 1992, el Programa Internacional para la Erradicación del Trabajo Infantil (IPEC), cuyo objetivo fue implementar programas de acción concretas que fueran más allá de normas jurídicas y que, hoy en día, es considerado el caballo de batalla de la OIT. Finalmente, en 1999, con la Convención no. 182, se creó un nuevo instrumento que apunta a la erradicación del trabajo infantil en sus "peores formas" y que fue presentado como el arma que, ahora sí acabaría de manera definitiva con el trabajo infantil, tal como estaba previsto desde la Convención no. 138 (LIEBEL, 2003).

${ }^{31}$ Oficina Internacional del Trabajo: La eliminación del trabajo infantil: un objetivo a nuestro alcance. Informe global con arreglo al seguimiento de la Declaración de la OIT relativa a los principios y derechos fundamentales en el trabajo. Informe del Director General para la Conferencia Internacional del Trabajo, 95ta reunión, 2006. Ginebra, 2006.
} 
de inclusão social, como por exemplo: (PETI, Bolsa Família, Fome Zero, Bolsa Escola e outros). $\mathrm{Na}$ verdade, o que está em jogo, enquanto pauta para a academia e os movimentos sociais, é fato de que, essas políticas exigidas pelas instituições financeiras gestoras do capital internacional e executadas servilmente pelos governos, visam, primordialmente e, isso é fundamental, ao falarmos de exploração do trabalho de crianças, à desregulamentação do trabalho, à flexibilização, à individualização do contrato de trabalho, à privatização da educação, dos sistemas de saúde e dos serviços públicos, enfim, à destruição da classe trabalhadora (SILVA, 2003).

\section{Sobre as relações entre trabalho, corpo, "tempo livre" e lazer na infância.}

Ao investigar a exploração do trabalho infantil, senti necessidade de fazer considerações acerca das possíveis relações entre trabalho/lazer, trabalho/tempo livre/capitalismo, lazer/lúdico e lazer/trabalho/infância. Tais nexos são imprescindíveis, devido ao processo de adultização precoce das crianças na esfera laboral, tornar tênues as diferenças entre ser criança e adulto trabalhador na lógica da exploração capitalista.

Com relação ao termo lazer, considero importante destacar que, apesar desta investigação conter em seu título e em seu corpo esta palavra, o seu emprego se dá, de uma lado, pelo seu uso corrente tanto no senso-comum quanto na produção acadêmica, em virtude desta expressão estar diretamente vinculada ao tempo ligado ao trabalho produtivo e assalariado dos trabalhadores adultos no mundo do trabalho capitalista. De outro lado, pretendi, intencionalmente, utilizá-la, visando deixar claro os sentidos dela, enquanto uma categoria recorrente ao capitalismo e permeada de questões epistemológicas e ideológicas, relacionadas à inserção prematura das crianças no mundo do trabalho alienado, pesado, insalubre, escravo. Portanto, a expressão lazer, aplicada à infância, justifica-se dadas às similitudes da inserção da criança e do trabalhador adulto no processo produtivo: exploração, relações desumanas de trabalho, extensas jornadas de trabalho, salários de miséria, etc..

O lazer é oriundo da sociedade burguesa e está de forma imbricado ligado ao tempo de trabalho, sobretudo no que diz respeito ao tempo destinado às jornadas de trabalho e ao conseqüente preenchimento do tempo liberado com o consumo de mercadorias. Neste sentido, a redução das jornadas de trabalho diária ou semanal, tem sido, desde o surgimento do capitalismo, a centralidade e a condição preliminar das lutas dos trabalhadores em prol do Direito à Preguiça, enquanto possibilidade de 
emancipação destes contra as opressões dos dogmas do trabalho, em suma, da expansão da superexploração capitalista. Estas reivindicações se constituíram e se constituem ainda, num importante mecanismo de contraposição à extração do sobretrabalho, realizada pelo capital, desde sua gênese com a revolução industrial e na contemporaneidade com a acumulação flexível do toyotismo e da máquina informacional (Antunes, 1999 p. 15-17).

De acordo com o autor supracitado (1999: 15-17), a lógica societal, na qual estamos imersos, é voltada para a produção de mercadorias e para a valorização do capital, do trabalho abstrato, do trabalho morto. Esta lógica, por conseguinte, forja a produção de corpos-mercadoria. Mais ainda, engendra um tempo sob os desígnios do trabalho abstrato, que se constitui num tempo abstrato de trabalho e de lazer, isto é, tempo vazio e linear já inscrito em nossas subjetividades (Kurz, 1988: 45-46) ${ }^{32}$, numa submissão voluntária aos ditames temporais da ditadura do tempo abstrato (grifos meus). Perspectiva temporal essa, que também ocupou o lazer (Ibidem) ${ }^{33}$ e que não se constitui num tempo verdadeiramente livre, uma vez que este foi transformado num consumo de mercadorias de crescimento constante. Deste modo, o vazio da aceleração impregnou o que restou da vida, antes dotada de sentido, as formas raquíticas de descanso foram substituídas por formas de hedonismos idiotizadores de consumo, portanto, mortas de sentido, cuja função é, dentro da lógica pós-moderna, estimular os sentidos para a sociedade do entretenimento, centrada no forte aparato antidemocrático e excludente das novas tecnologias. Nestes termos, essa sociedade do espetáculo (DEBORD, 1997), do tempo efêmero, quantitativo, fragmentado e eivado pelo consumo banal de mercadorias bizarras, termina por atuar como elemento dinâmico nas transformações do imaginário, na sensibilidade e nos sistemas de percepção das populações, sobretudo, das megacidades modernas ${ }^{34}$. O lazer é na sociedade capitalista apenas um privilégio de poucos, privilégio dos ricos e, por este motivo, é uma questão de relevância pública, considerando que boa parte dos trabalhadores que atuam no setor, tanto formal quanto informal da economia, executam jornadas excessivas de trabalho, dispondo, portanto, de quase nenhum tempo efetivamente livre para a vivência dos lazeres. Isto significa dizer que o tempo livre e o tempo de trabalho aparecem atualmente implicados na mesma alienação, pois numa sociedade dividida, seja qual for a forma que se configure, como atividade de produção ou como atividade de consumo

\footnotetext{
${ }^{32}$ Cf. Anais do V Congresso Mundial de Lazer, São Paulo, Nov./1988.

${ }^{33}$ Cf. Cf. Entrevista concedida ao Caderno Mais, Folha de São Paulo, 23/01/2000, p 5-3.

${ }^{34}$ Cf. Nicolau Sevcenko (Folha de São Paulo, Caderno Mais, 09/01/ 2000).
} 
(indústria do lazer), é igualmente posta à disposição da potência estranha que o domina e que continua a criar (Manacorda, 1991:192). Em outras palavras, se tomarmos a categoria lazer enquanto consumo da sociedade capitalista, produtora e consumidora de mercadorias e tendo como premissa as chamadas indústrias do lazer e indústria da cultura, chegaremos à conclusão de que suas mazelas compensatórias, fetichizantes e abstratas, são oriundas do próprio mundo opressivo e objetivado do trabalho. Sendo assim, faz sentido dizer que (...) se no trabalho e no lazer corre o mesmo sangue social, é de se esperar que a alienação de um gere evasão e processos compensatórios em outros (Bosi, 1981: 86). Contudo, formas de resistência no que se refere a "compatibilidade entre capitalismo e tempo livre". Estou me referindo, as lutas que os sindicatos e movimentos sociais empreendem, no âmbito capital-trabalho, visando, garantir os direitos dos trabalhadores e o trabalho, ontologicamente, compreendido como a centralidade do ser social.

A racionalidade capitalista, todavia, convém de novo reforçar, interessa-se apenas pelo tempo de produção, o tempo descartável, fragmentado, mercantilizável/mercantilizado. Ela despreza por completo o tempo dos homens; o tempo social, qualitativo; tempo subjetivo e agente de criação, história e cultura; tempo total, integral, simultâneo, passado, presente-futuro fundidos em instantes de plenitude; tempo de repetição criativa dos jogos infantis, tempo de lentidão, da contemplação ; tempo do lúdico; tempo da formação humana; tempo do corpo brincante, enfim o tempo kairós A desumanização da racionalidade capitalista, despreza completamente o sangue que palpita nas veias do homem que trabalha, seus desejos, seus sonhos, substituindo-os pelos tempos burocratizados, agendados e institucionalizado; pela relação tempo-volume, pela quantidade, pela velocidade do tempo amalgamada em dinheiro, em lucro; tempo de formação profissional, tempo do corpo produtivo, tempo cronos (PERROTTI, 1990; GARCIA, 2007; SILVA, 2003). Essas reflexões sobre o tempo social como dimensão construtiva histórico-social, baseia-se na $b i$ dimensionalidade do tempo como o melhor recurso teórico-metodológico para conceber o tempo social e suas formas. Todo esse trajeto pretende decifrar o tempo sempre duplicado em pares dialéticos, que informam: a escala e a repetição, a transformação e a permanência, o instante e a duração, o kronos e o kairós (GARCIA, 2007).

O sistema de racionalidade produtiva inviabiliza o tempo do lúdico, cuja lógica não é regulável, mensurável, objetivável, lucrativa. Assim é que ao tentar subordiná-lo e 
atrelá-lo ao tempo de produção ocorre sua descaracterização, sua mutilação, sua morte (PERROTTI, 1990: 20). E o que acontece com o lazer, não é isso? Não é a deformação do lúdico, morto, massificado, sem criatividade, sem liberdade, sem sentido, uma vez que está preso aos esquemas do tempo-mercadoria, do corpo-mercador e ao mesmo tempo corpo-mercadoria como na exploração do trabalho infantil?

O que acontece é que o lúdico, na verdade, é cada vez mais banido ou vivenciado de modo subversivo, portanto, ele é permitido apenas nas searas discriminadas dos improdutivos, dos criativos, dos lentos, dos transgressores. No âmbito da lógica da produtividade o lúdico constitui a negação desta e a prova inconteste de sua incompatibilidade com o sistema produtor de mercadorias. Assim é que, ao invés do lúdico coloca-se em seu lugar o simulacro de criação, sentimento, diversão e festa; coloca-se em seu lugar o lazer, o não-trabalho, que na verdade é completamente diverso do lúdico, pois, este se identifica com o jogo, com a brincadeira, com a criação contínua, ininterrupta, intrínseca à produção (Perroti, 1990: 18-27).

Efetivamente, o tempo do lúdico nunca poderá atrelar-se e imiscuir-se com o tempo da produção capitalista, porque neste último está circunscrito o consumo, o estranhamento, a separação entre o econômico, o cultural e o social. O lúdico, portanto, não se identifica com os valores do lazer capitalista. Ele identifica-se de forma latente com a criança, cuja subjetividade não está apta para o sistema produtivo, tendo em vista o espírito da racionalidade não ter conseguido ainda domá-la. Todavia, é este sistema que teima em domesticá-la para o trabalho prematuro e explorador, insiste em desumanizá-la, transformando-a de ser social para coisa, mercadoria dócil. No entanto, vive seus jogos e brincadeiras, continuando o curso da construção da cultura lúdica, vivendo a meu ver, utilizando a expressão do autor supramencionado a desalienação á revelia do sistema dominante (Ibidem: 21-22). Todavia, apesar das transgressões e protestos simbólico-reais as crianças poderão, com o tempo, ser pressionadas pela necessidade e privação, sucumbindo, assim, a esta racionalidade. Por outro lado, conforme presenciei isto no trabalho de campo, poderão apresentar sinais de uma extraordinária força subversiva através dos atos lúdicos. Todo esse esforço revela o desejo das crianças de refazer, desconstruir, reconstruir, enfim, recriar a vida cotidiana, a história, o tempo, a sociedade.

Toda essa reflexão sobre o tempo social se situa na perspectiva das políticas do corpo, principalmente, num momento histórico em que, no limiar das diferenças abissais entre as classes sociais, se distingue uma cultura corporal, cujas práticas 
corporais mercadorizadas, fundadas nos cânones de beleza, destinam exclusivamente ao consumo das elites, ou melhor, como diz Santos (1999:14-15) às classes obesas. No barco desse movimento contraditório da história, as crianças da classe trabalhadora, são obrigadas a construir suas práticas corporais, predominantemente através do trabalho alienado, precário, insalubre e pesado. Porém, isto não podre ser visto de forma monolítica, considerando que esses mesmos corpos se expressam através da cultura lúdica popular, sobretudo, através dos jogos e práticas tradicionais de lazer - hoje quase em extinção em virtude da não apropriação e usufruto do suposto e inexistente tempo livre por parte dos trabalhadores assalariados.

Quando me proponho a discutir o corpo das crianças exploradas pelo trabalho, o faço pelo fato de este representar uma importante categoria de análise emergida do real, porém, convém lembrar que durante toda a pesquisa, o corpo é representado pela noção de sujeito. Nestes termos, estou o tempo todo falando do sujeito-corpo, do sujeito trabalhador produtivo e, ao mesmo tempo, brincante, cuja história social e cultural é construída em diálogo contínuo com o mundo da racionalidade, sensibilidade, enfim, de diversas facetas da vida cotidiana como a política, o trabalho, a religião, a sexualidade, a ludicidade e outras. Todo esse arcabouço está maculado nessa unidade que se constitui o ser humano, isto é, no corpo, esta superfície da natureza humana que se traduz na materialidade do ser social frente ao mundo.

Esses sinais impressos nos corpos dos trabalhadores pelo neoliberalismo podem ser constatados nos corpos produtivos que são a representação real do trabalho produtivo, isto é, trabalho humano abstrato e não deste como atividade vital e emancipatória.

O corpo produtivo, portanto, opera, como veremos, através da mediação entre $o$ social e o biológico sob a égide do trabalho socialmente necessário, cujo fim único é trabalhar para manter-se e satisfazer as necessidades básicas e, conseqüentemente, produzir/trabalhar para tornar mais rentável o capital.

De acordo com Luc Boltanski em seu livro O corpo e as classes sociais, há uma relação entre a Sociologia do Corpo, Sociologia do trabalho e classe social, considerando que categoria corpo se impõe, sobretudo pela presença do trabalho alienado e, conseqüentemente, pela manifesta degradação das condições de vida corporal das populações rurais, no que tange à materialidade biológica, cultural, política, econômica e social. Nesta perspectiva, os usos do corpo na sociedade 
capitalista, têm suas determinações primeiras que podem ser buscadas no sistema produtivo (Boltanski, 1989).

\section{Considerações quase finais...}

No ponto de vista de resultados advindos das intervenções nos dez EventosCampos, é preciso levar em conta as considerações parciais e provisórias de cada intervenção em campo, articuladas com as questões de pesquisas emergidas no contexto do fazer investigativo cotidiano quase que de natureza longitudinal. Em vista disso, considero essencial retomar as questões de pesquisa formuladas no início e durante o processo de investigação: "a lógica da exploração capitalista, com toda a sua carga destrutiva do trabalho alienado, conseguiu suprimir total ou parcialmente o tempo livre" das crianças para o usufruto da cultura lúdica? Além disso, se os dados encontrados na tese de doutoramento (2000) e no projeto do livro "Trama Doce-Amarga: (Exploração do) Trabalho Infantil e Cultura lúdica”, publicado por mim em 2003 - ainda prevalecem ou sofreram modificações ao longo dos últimos quatro anos - em razão das ações da OIT e das políticas sociais do governo brasileiro? Finalmente - é possível erradicar o trabalho infantil pela raiz na perspectiva da lógica do capitalismo neoliberal, não só na zona canavieira do estado de Pernambuco, mas em todo o Brasil, considerando as novas configurações do mundo do trabalho (desemprego, precarização, flexibilização)?

Após um longo período de intenso engajamento neste processo de investigação, percebo que o que resultou deste tempo foram às relações sociais de alteridade. Estas relações foram travadas num tempo fortemente marcado por significativas sociabilidades, confabulações, pactos e afetos, política e cultura. Além disso, foi um caminho percorrido nas trilhas do projeto histórico e social dos sujeitos. Sinto-me sensibilizado também pelas suas obstinadas lutas pela sobrevivência e pelo imenso potencial de rebeldia, sonho, desejo e dignidade, pois, nos meandros de suas vidas cotidianas, o capitalismo deixou o seguinte suspiro em seus corpos: quando se descansa se carrega pedra. Talvez tenha sido este o maior achado, a maior novidade desta pesquisa esse dado está além da estatística e passados 11 anos de experiências investigativas, me parece que pouca coisa mudou, pois, na região canavieira pernambucana, as maiorias das usinas permanecem fechadas, as pessoas a migrar para os grandes centros urbanos (Recife e outras cidades do Sul e Sudeste do Brasil), o 
desemprego é cada vez maior, a fome e a miséria continuam lado a lado, seguindo seus cursos por entre latifúndios, devastações da Mata Atlântica, rios e canais poluídos, palafitas, mães solteiras desde a mais tenra idade, exploração-escravidão, sub-emprego e desemprego, escolarização precária, mas inclusiva! Por outro lado,

Em geral as respostas foram provisoriamente respondidas pelos sujeitos na prática concreta da pesquisa, por mim e pelos diversos autores e pesquisadores. São questões que inegavelmente foram respondidas à luz do real e indicam os dilemas, impasses e constrangimentos por que passam as crianças e suas famílias vilipendiadas pela ação destrutiva do capital. Outrossim, algumas questões carecem, de maneira mais amiúde, de ser respondidas em outras investigações; outras podem ser refutadas e devem seguir o curso da dúvida, da incerteza e da busca permanente das causas, conseqüências e raízes históricas dessas problemáticas sociais. No entanto, boa parte dessas questões colocadas estão carregadas de respostas concretas que as próprias denúncias e sonhos-desejados dos sujeitos nos apontam, enquanto chave para a interpretação e análise da realidade dominada pela propriedade fundiária na cana-deaçúcar. São questões que já vêm sendo problematizadas, denunciadas, alertadas e rechaçadas pelos pesquisadores e movimentos sociais, mas que seguem o curso da história, repetindo-se, complexificando-se, agravando-se.

Durante todo o processo de construção da pesquisa e, até hoje, ficaram nítidas as conseqüências da crise do capitalismo, nas quais estão nitidamente marcados os efeitos da acumulação flexível neoliberal e suas repercussões e mutações sob o mundo do trabalho da cana-de-açúcar. Estas mudanças são engendradas pelos gestores do capitalismo internacional (FMI e Banco Mundial), através dos Planos de Ajuste Estrutural. Portanto, pode-se dizer que as repercussões da Globalização da Economia, no que diz respeito à crise e seus impactos da reestruturação produtiva na região da Zona da Mata açucareira pernambucana, vêm produzindo de forma avassaladora a destruição da força humana de trabalho, do meio ambiente, da família, da infância, da juventude e da velhice.

Outro tema digno de debate crítico é a questão do PETI/Mão Amiga (Programa de Erradicação do Trabalho Infantil), cujos pressupostos ideológicos são postos em prática, através do assistencialismo e do clientelismo. Estas políticas ou programas institucionais, de natureza pasteurizadora e reprodutora da pobreza secular, terminam provocando uma forma de inclusão temporária, precária e marginal do ser social criança e de toda a sua família. 
Os dados continuam a revelar a existência de doces jogos em meio a vidas amargas, vidas essas, em cujos corpos sociais estão impressas as tatuagens históricas da barbárie da exploração capitalista. Em contrapartida, trouxeram à tona alguns elementos para a compreensão, crítica e análise do mundo do lazer/lúdico das crianças e adultos explorados pelo capital. Nesta perspectiva, quanto ao chamado tempo livre, ficou evidenciada na pesquisa de campo, a incompatibilidade do usufruto de um tempo efetivamente livre na perspectiva da lógica de produção de mercadorias do capitalismo, do trabalho coisificado, explorador. Ficou claro, por conseguinte, que numa realidade marcada pela exploração e pela privação, a alienação tem sua morada tanto no trabalho quanto no tempo de lazer. Portanto, na minha opinião, respaldado pelo que dissera Antunes (1999), só é possível uma vida dotada de sentido fora do trabalho se dentro deste (trabalho) também existir uma vida dotada de sentido. Esta afirmação continua a vigorar sempre, enquanto prevalecer o modo de produção capitalista.

Mesmo considerando a incompatibilidade entre tempo livre e capitalismo, foi possível perceber que, apesar da miséria em que vivem, os sujeitos possuem rebeldia, humor, fazem festa, brincam de roda, inventam histórias, causos e jogos, protestam nas campanhas salariais, reagem, participam dos movimentos sociais e lutam pela desalienação do ser humano, lutam, finalmente, pela conquista do ainda não alcançado: tempo livre!

Esta pesquisa traz também em seu contexto as reflexões acerca das relações Corpo, Sociedade e Classes Sociais, especificamente sobre os corpos das crianças, adultos e velhos trabalhadores da cana-de-açúcar (e também da zona urbana), envelhecidos precocemente e que na vida cotidiana se convertem em produtores de riqueza e mais-valia para outrem, em valor de troca. Os corpos-sujeitos continuam envelhecendo e perdendo gradativamente seus direitos.Entretanto, tendo em vista os dois eixos teórico-metodológicos pobreza e riqueza da vida cotidiana, pude captar do movimento do real o corpo produtivo e o corpo brincante. Assim, por um lado, veio para roda de discussão o trabalho produtivo que gera corpos produtivos, cujas forças de trabalho (físicas e intelectuais) são apropriadas pelo capital, tendo em vista a sua perpetuação, sendo, portanto, produtivos porque são engendrados através da mediação entre o corpo biológico e o corpo social. Por outro lado, destaca-se no mesmo corpo social o corpo brincante, lúdico ou da festa, quer dizer, aquele que é produtor de outros tipos de riqueza humana: os jogos, as danças, alegria, a festa e a cultura e, que apesar da degradação a que é submetido, também se impõe enquanto corpo-sujeito produtor de 
uma outra subjetividade gestada à luz dos valores do lúdico: gratuidade, sentimento, beleza, criatividade, prazer, solidariedade, fantasia, mistério, sonhos-desejados e resistências. Trata-se, enfim, de um corpo produtor de outros elementos ontológicos, isto é, éticos, políticos estéticos, forjados, principalmente, nos resíduos de tempo fora dos esquemas do trabalho alienado.

Respondendo, especificamente, à questão: o lazer/lúdico, o gato comeu? Percebi que o tempo residual das jornadas de trabalho e destinado à vivência dos jogos e brincadeiras pode ser compreendido em três dimensões: supressão, vivência plena e parcial. Neste âmbito, os diversos Eventos-campos trouxeram à tona, através dos vários instrumentos utilizados (entrevistas, observações, fotografias, desenhos e documentos), os seguintes resultados: crianças que não brincam, crianças que brincam pouco, crianças que brincam plenamente. Contudo, predomina a tendência das crianças terem pouco tempo para o lúdico, em função das extensas jornadas de trabalho, provavelmente na cana, em atividades laborais clandestinas e invisíveis, na escola e nas tarefas domésticas (tanger gado, buscar água, e outras). Isto posto, observei que, apesar de algumas crianças terem mencionado que não brincam, que o brincar é tão inerente a elas: de fato, muitas vezes elas brincam no sonho, no imaginário, no sonho-desejado.

Ficou evidenciado que os jogos e brinquedos das crianças são construídos no terreno da adversidade e da penúria, na sucata e migalhas de tempo conquistadas a duras penas. O lúdico nestes meandros é tecido na boca-da-noite, na boca-de-forno, na natureza quase morta, no tempo morto, mas ainda assim, da maneira mais criativa e rebelde possível. Os jogos das crianças se constituem em brincadeiras tradicionais, tais como: subir em árvores; caçar passarinhos; jogar futebol; brincar de roda, atirar flechas de folha de cana; imitar os animais domésticos: galo, jegue, boi, vaca. Brincando desse jeito, elas mitigam o sofrimento; pulam a corda bamba do destino; pulam academia (amarelinha); dão nó em pingo d'água; viram cambalhotas no ar, tentando talvez um dia alcançar a outra academia, a escola; driblam, em suma, com o lúdico da bola de seus mundos os jogos perversos do capital, que as fazem exilar-se, ainda que sob protestos veementes, das suas próprias infâncias.

Durante toda a pesquisa observei a seriedade com que as crianças tecem as teias do brincar, através da permanente disposição para o ócio contemplativo, produtivo e útil para a manifestação da liberdade, e dos desejos. Portanto, a idéia do ócio é entendida como um tempo de produção cultural que não tem preço e não dá lucro, porque opera no cotidiano de seres sociais e não de mercadorias, por conseguinte, construindo afetos, 
comunicação, fantasias, mistérios e interação social. As crianças, independentemente do mundo do trabalho a que fazem parte (cana, sisal, carvão, hortaliças, laranja e outros), possuem o mesmo desejo, isto é, não querem um tempo não-residual do trabalho estranhado, mas um tempo articulado entre a escolarização e o lúdico. Em suma, as crianças demonstram que o jogo é a centralidade de suas vidas, pois, estão sempre em prontidão para qualquer tipo de brincadeira, para qualquer tipo de confabulação lúdica, estão sempre preparadas para inventar e reinventar a roda do mundo, a vida cotidiana; estão sempre a dar um belo exemplo de cidadania para os adultos, através de suas transgressões e resistências ao poder capitalista constituído.

Após toda a experiência acumulada na pesquisa de campo e o diálogo com os autores referenciados nesta pesquisa, conclui que não é possível a erradicação do trabalho infantil no capitalismo. Não é possível extirpar o trabalho infantil, isto é, arrancá-lo pela raiz e pôr fím ao furto do tempo de lazer/ lúdico e à degradação da infância, sem que haja, como já se anuncia, uma verdadeira onda de rebeldia e inconformismo e desobediência civil dos trabalhadores em nível local, nacional e mundial. Por outro lado, penso que sim; é possível erradicar o trabalho infantil no capitalismo! Mas, para tanto é preciso desconstruir os discursos da OIT, do UNICEF, das políticas sociais do governo brasileiro e de algumas ONG's que fetichizam os dados estatísticos forjados por estas mesmas instituições (OIT), a partir de métodos de medição que, claramente, insinuam a diminuição das taxas do trabalho infantil com base, unicamente, no discurso jurídico, celebrando, assim, a suposta erradicação deste tipo de trabalho (des) humano.

No meu entender, continuo afirmando que são falsas, abstratas e não-críveis as promessas neoliberais, pelo fim da exploração do trabalho infantil, uma vez que a exploração é necessária e inerente à própria perpetuação do modo de produção capitalista. Dito isto, sustento a opinião de que, enquanto o ser social estiver imerso no reino da necessidade e sob a regência da exploração generalizada e da potência estranha que o domina, não é possível radicalmente falar-se em emancipação da condição humana, da infância, da cidadania.

Embora tenha constatado que as crianças brincam em condições adversas de tempo e espaço ou simplesmente através do imaginário onírico e de seus sonhos desejados penso que, o que está em jogo não é o jogar em si, a resistência em si. O que realmente está em jogo no meu entendimento é o fato delas brincarem numa realidade destruída pela racionalidade capitalista e, mesmo assim, se imporem enquanto seres 
sociais, resistindo ludicamente, apresentando, simbolicamente, um outro projeto de sociedade. Isto significa dizer que o tempo exíguo para o lúdico também carrega consigo as marcas históricas da pobreza, da privação, do trabalho estranhado, do cerceamento, da justiça, da má distribuição da renda e da terra.

Não foi por acaso que cheguei a essas reflexões provisórias, mas pela compreensão de que, enquanto pesquisador e cidadão, o outro também sou eu e as reivindicações e sonhos-desejados dos sujeitos pela desalienação do tempo de trabalho e do lazer também coincidem com o projeto socialista que acredito. Nesta linha de raciocínio, todas essas conquistas só serão possíveis de ser realizadas à luz de políticas sociais revolucionárias, eqüitativas e estruturadoras: trabalho concreto reforma agrária, crédito agrícola, educação pública gratuita e de qualidade, saúde e previdência social. Portanto, cheguei a essas conclusões, considerando a história do sofrimento cunhada nos corpos de trabalhadores vilipendiados pelo capital e através dos reclamos das suas vozes eivadas de indignação:

\footnotetext{
(...) Rapaz a gente colocou um nome na cana-de-açúcar, que ela tem um gosto de sangue, então, o nome dessa sua tese não é exagerado não, pois, a vida é amarga mesmo. $\mathrm{O}$ açúcar é doce, mas pra fazer dá uma suadeira triste. O lazer o gato comeu! O emprego o gato comeu! O salário o gato comeu! (Palavras do Presidente do Sindicato dos Trabalhadores Rurais de Rio Formoso, Evento-Campo 03).
}

\section{BIBLIOGRAFIA}

AHLERT, Alvori. "Exclusão" "versus" Qualidade Ética da Educação. In: BONETI, Lindomar (Coord.) Educação, exclusão e cidadania. Ijuí: Ed. Ijuí, 1997.

ANTUNES, Ricardo. Os Sentidos do Trabalho: Ensaio sobre a afirmação e a negação do Trabalho. São Paulo: Boitempo, 1999.

. Adeus ao Trabalho. Campinas/SP: Editora da Unicamp, 1995.

CASTEL, Robert et alii. Desigualdade e a Questão Social. São Paulo: Educ/PUC, 1997. 
Da Indigência À Exclusão, a Desfiliação: Precariedade do Trabalho e vulnerabilidade Relacional. In: DONZELOT, Jacques. (Org.). Face a L'exclusion: le modèle Français, p. 137-168, 1991.

COGGIOLA, Osvaldo (Org.). Globalização e Socialismo. São Paulo: Xamã, 1997.

CHOMSKY, Noam. Segredos, Mentiras e Democracia. Brasília: Ed. UNB, 1997.

CHOSSUDOVSKY, Michel. A Globalização da Pobreza: Impactos das reformas do FMI e do Banco Mundial. São Paulo: Moderna, 1999.

DOURADO Ana. Crianças e Adolescentes nos Canaviais de Pernambuco. In: DEL PRIORE, Mary. História das Crianças no Brasil. São Paulo: Contexto, 1999.

ENGELS, F. A Situação da Classe Trabalhadora na Inglaterra. São Paulo: Global, 1985.

FORRESTER, Viviane. O Horror Econômico. São Paulo: Ed. da Universidade Estadual Paulista, 1997.

GARCIA, Guadalupe Valencia. Entre Cronos e Kairós: Lãs formas del tiempo sociohistorico: Rubi Barcelona: Anthropos Editorial; México: UNAM. Centro de Investigaciones Interisciplinares em Ciências y Humanidades, 2007.

GAlEANO, Eduardo. As Veias Abertas da América Latina. Rio de Janeiro: paz e Terra, $22^{a}$ ed. 1986.

HELlER, Ágnes. Sociologia de la Vida Cotidiana. Barcelona: Ediciones Peninsula, 1994

KOSIK, Karel. Dialética do Concreto. Rio de Janeiro: Paz e Terra, 1976.

MACHADO, Lucília R. de Souza. Politécnia, Escola Unitária e Trabalho. São Paulo: Cortez, Autores Associados, 1989.

MANACORDA, Mario A. Marx e a Pedagogia Moderna. São Paulo: Cortez/Autores Associados, 1991.

MARTINS, José de Souza (Org.). O Massacre dos Inocentes. In: Ibidem (Org.).Regimar e seus amigos - A criança na luta pela terra e pela vida. São Paulo: Hucitec, 1993. 
MARX, K. ENGELS F. Trabalho Alienado. In: Fernandes, Florestan (Org.). Karl Marx e F. Engels: História, São Paulo: Ática, 1978.

MARX, Karl. O Capital: Crítica da Economia Política. $3^{\mathrm{a}}$ ed. São Paulo: Nova Cultural, 1988.

. Manuscritos Econômico-Filosóficos e Outros textos Escolhidos. São Paulo: Abril Cultural, 1978.

MÉZÁROS, Istvan. Para Além do Capital. São Paulo: Boitempo, 2005.

MOURA, Esmeralda Blanco B. Infância Operária e Acidente de Trabalho em São

Paulo. In: História da Criança no Brasil. Del Priore, Mary (org.) $2^{\mathrm{a}}$ ed., São Paulo: Contexto, 1992.

NEVES, Delma Pessanha. A Perversão do Trabalho Infantil. Niterói: Intertexto, 1999.

NOGUEIRA, Maria Alice. Educação, Saber, Produção em Marx e Engels. São Paulo: Cortez, 1990.

ORGANIZAÇÃO INTERNACIONAL DO TRABAHO. Bibliografia sobre o Trabalho de crianças e Adolescentes no Brasil. São Paulo: Secretaria da Criança, Família e Bem-Estar Social, 1994.

PINHEIRO Paulo Sérgio. A Classe Operária no Brasil. São Paulo: Brasiliense, 1981.

PISTRAK, M. M. Fundamentos da Escola do Trabalho. São Paulo; Ed. Expressão Popular, 2000.

REIS FILHO, Daniel. O Manifesto do Partido Comunista 150 Anos Depois. Rio de Janeiro: Contraponto, 1998.

RIZZINI, Irma. Pequenos Trabalhadores do Brasil. In: DEL PRIORE, Mary. História das Crianças no Brasil. São Paulo: Contexto, 1999.

SANTOS, Boaventura de Sousa. (Org.). A Globalização e as Ciências Sociais. São Paulo: Cortez, 2002.

SARMENTO, Manuel Pinto. Revista Conferências, Uminho, 2007, no prelo. 
SILVA, Maurício R. Trama doce-Amarga: (Exploração do) Trabalho Infantil e Cultura Lúdica. São Paulo: HUCITEC; Ijuí: UNIJUÍ, 2003.

SILVA, Maurício R. Esporte, Educação, Estado e Sociedade: As políticas públicas em Foco. Chapecó, SC: Editora ARGUS, Unochapecó, 2007.

SILVA, Maurício Roberto. Trabalho Infantil ou Exploração do trabalho Infantil? In: Redin, E. et alii. Infâncias: Cidades e escolas amigas das crianças. Porto Alegre: Mediação, 2007.

SCHWARZMAN, Simon. As Causas da Pobreza. Rio de Janeiro: Editora Fundação Getúlio Vargas, 2004.

SUTTON-SMITH. Die Dialektik des Spiels. Schordorf, Deutschland: Homan Verlag, 1978.

TAFFAREL, Celi. Política científica e produção do conhecimento na Educação Física/Ciência do Esporte: A conjuntura, as contradições e as possibilidades de superação. In: CARVALHO, Yara M. e LINHALES, Meily A. Política científica e produção do conhecimento em Educação Física. Goiânia: colégio Brasileiro de Ciências do Esporte, 2007.

TRIBUNAL INTERNACIONAL CONTRA O TRABAHO INFANTI/ SÃO PAULO-II SESSÃO. Sentença. São Paulo, 1999, mimeo.

TRIBUNAL NACIONAL CONTRA O TRABALHO INFANTIL/ MÉXICO - I SESSÃO. Sentença. Revista Motrivivência, nº 8, 1996.

UNICEF. A Infância Brasileira nos Anos 90. Brasília, DF: UNICEF, 1998.

UNICEF. Estado Mundial de la Infância 1977. Genebra: UNICEF, 1977. 